\title{
Sequential Physical Activity Model to Improve Motor Ability in Early Children
}

\author{
Hadwi Prihartanta ${ }^{1}$ Panggung Sutapa ${ }^{1}$, Suharjana Suharjana ${ }^{1}$, Muhammad Sigit \\ Antoni $^{1 *}$
}

\author{
${ }^{1}$ Department of Sports Science Universitas Negeri Yogyakarta, Yogyakarta, Indonesia \\ *Corresponding author.Email: sigitantoni@uny.ac.id
}

\begin{abstract}
Early childhood education carry out physical activities that can develop both cognitive and motor skills. The results of many observations in Kindergarten schools do not have enough yards for their students to play, thus the physical education process cannot be carried out optimally. Sequence physical activity is one of the options that can be used as an alternative to the implementation of physical education in kindergarten with simpler infrastructure can provide more benefits. This study tries to determine the effect of providing a series of sequence physical education learning models to improve motor skills in early childhood. This is experiment research used one group that received series sequence physical activity treatment. The number of samples used in this study amounted to 40 children aged 56 years treated with sequence physical activity consisting of 5 stations. The result of this study was that physical education learning based on a series can improve children's motor skills, it is proven that in the statistical test $\mathrm{P}>0.05$. Physical education learning based on a series has a pressure point in providing stimulation of motor skills.
\end{abstract}

\section{Keywords: Sequential, Physical Activity, Motor Ability, Children}

\section{INTRODUCTION}

Early childhood education is the duty of all parties involved in creating the groundwork for a child's growth in all areas prior to joining school. During this stage, there is a lot of growth and development. Parents go to great lengths to ensure that their children grow up to be healthy and robust. Involving children in lay activities is one of the measures done. Basic education is given precedence over early childhood education. This is significant because a person's potential is generated and developed throughout this time, since childhood is regarded as the golden age. Kindergarten education is formal education organized in an effort to help lay the foundation for development in all aspects before entering school. At this age, growth and development takes place very quickly and at this age also really needs stimulation for further development [1][2].

In kindergarten, children carry out physical activities that can develop both cognitive and motor skills [3]-[5]. One of them can be done with a sequence physical activity. Sequence physical activity is one of the choices in the physical education learning process, because in the process of movement it is natural [6][7]. The availability of supporting media for learning physical education in order to stimulate motor skills is still very limited. In some Kindergarten schools, in carrying out physical education, the nature of the movement tends to be random and the media used is the teacher's voice. In the learning process of this model, the teacher's voice will indirectly affect the psyche of students. If the voice sounds high-pitched (angry) it will affect the learning atmosphere. Therefore, the evaluation carried out tends to focus on memorizing movements only. This condition has not touched the essence of the presence of physical education. The essential touch of physical education that is less than optimal [8].

In physical education, which in learning uses a lot of tools that it is possible to stimulate the motor skills of students. It caused by a lot of interaction with the tools [9]. These tools can be in the form of objects or in the form of instructions. For example, singing and mentioning one of the limbs to be moved according 
to the direction referred to, music as a regulator of the rhythm of motion, moving objects sequentially by color (patterned game) arranging blocks based on a sequence of numbers, counting the number of objects used to throw and counting the number of hits target, but this has not received optimal attention [10]. This is shown in the proportion of learning hours and more sitting in the classroom .

The results of many observations in Kindergarten schools do not have enough yards for their students to play, thus the physical education process cannot be carried out optimally [11]. Various limitations of infrastructure also cause the implementation of physical education in the kindergarten cannot be carried out optimally so that improvisation is needed in the implementation of physical education in the kindergarten [12]. Thus the process of physical education has not gone as expected, one of which is due to the lack of land besides that the teachers do not understand much about the role of physical education. The impact of this is that the use of physical education learning models is not widely developed, including the provision of support in the learning process.

scan be used as an alternative to the implementation of physical education in kindergarten. Besides being able to be done with simpler infrastructure, a physical activity sequence is also a series of activities that can provide more benefits [6]. This study tries to determine the effect of providing a series of sequence physical education learning models to improve motor skills in early childhood.

\section{METHOD}

The type of research conducted in this study is an experiment. This study used one group that received series sequence physical activity treatment. The number of samples used in this study amounted to 40 children, all of whom were aged 5-6 years, which then from a sample of 40 people after the initial test were then treated with sequence physical activity consisting of 5 stations. The sequence of the learning activities is arranged as follows: station I: walking on the catwalk, station 2: goal jumping, station 3: moving the baton, station 4: throwing the ball towards the target, and station 5: arrange blocks. The instrument used to measure gross motor skills consists of five items: (1) running speed of 25 meters, (2) throwing power of a tennis ball, (3) explosive power with long jumps without a prefix, (4) balance by walking on a catwalk. length of 4 meters and (5) Agility by running back and forth, turning past cones.
Table 1. Achievement of Success

\begin{tabular}{|c|c|c|c|c|c|}
\hline Score & $\begin{array}{c}\text { Station } \\
\mathbf{1}\end{array}$ & $\begin{array}{c}\text { Station } \\
\mathbf{2}\end{array}$ & $\begin{array}{c}\text { Station } \\
\mathbf{3}\end{array}$ & $\begin{array}{c}\text { Station } \\
\mathbf{4}\end{array}$ & Station 5 \\
\hline 5 & $>3.59$ & $<5.9$ & $<1.53$ & $>5.11$ & $>4.0$ \\
& & & & & \\
\hline \multirow{2}{*}{4} & $3.60-$ & $4.8-$ & $1.22-$ & $5.12-$ & $4.01-$ \\
& 4.02 & 5.8 & 1.52 & 6.76 & 4.53 \\
\hline \multirow{2}{*}{3} & $4.03-$ & $3.7-4.7$ & $0.91-$ & $6.77-$ & $4.54-$ \\
& 4.45 & & 1.21 & 8.41 & 5.06 \\
\hline 2 & $4.46-$ & $2.6-3.6$ & $0.60-$ & $8.42-$ & $5.07-$ \\
& 4.88 & & 0.90 & 10.06 & 5.59 \\
\hline 1 & $<4.89$ & $>2.5$ & $>0.5$ & $<10.07$ & $<6.00$ \\
\hline
\end{tabular}

\section{RESULT AND DISCUSSION}

\subsection{Result}

Learning that takes place in Kindergarten schools has always referred to the implementation of the curriculum, namely the formation of competencies in students, the basic competencies that are raised are still very simple. These competencies include one's own abilities including language skills, habituation, cognitive, physical/motor and artistic skills.

Based on the homogeneity test, the results of the homogeneity test were less than 0.005 so that the data obtained were not homogeneous. Based on the normality test, it is known that the data is normally distributed. From the data analysis, it can be concluded that the serial model activity can improve the motor skills of children $\mathrm{P}<0.05$.

Table 2. Test of Homogeneity of Variances

Test of Homogeneity of Variances

\begin{tabular}{|r|r|r|l|}
\hline Levene Statistic & df1 & df2 & \multicolumn{1}{l|}{ Sig. } \\
\hline 29.126 & 1 & 78 & .000 \\
\hline
\end{tabular}

Tabel 3. Table of One-Sample Kolmogorov-Smirnov Test

\begin{tabular}{|ll|r|r|}
\hline & & \multicolumn{1}{|c|}{ Before } & \multicolumn{1}{c|}{ After } \\
\hline $\mathrm{N}$ & Mean & 40 & 40 \\
Normal & 17.15 & 24.30 \\
Parameters & & 2.694 & 1.091 \\
& Std. & & \\
& Deviation & .174 & .364 \\
Most Extreme & Absolute & .113 & .261 \\
Differences & Positive & -.174 & -.364 \\
& Negative & &
\end{tabular}




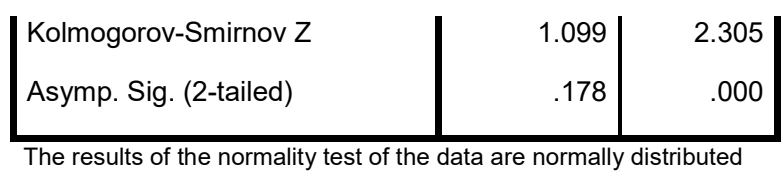

Tabel 4. Paired Samples Statistics

\begin{tabular}{|rl|r|r|r|r|}
\hline & & Mean & $\mathrm{N}$ & \multicolumn{1}{c|}{$\begin{array}{c}\text { Std. } \\
\text { Deviation }\end{array}$} & \multicolumn{1}{|c|}{$\begin{array}{c}\text { Std. Error } \\
\text { Mean }\end{array}$} \\
\hline Pair 1 & Before & 24.30 & 40 & 1.091 & .172 \\
& After & 17.15 & 40 & 2.694 & .426 \\
\hline
\end{tabular}

Tabel 5. Paired Samples Test Result

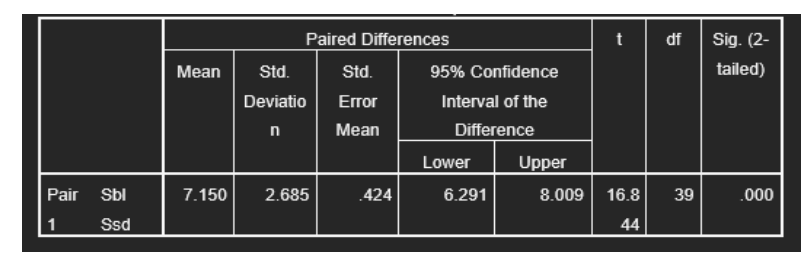

Table 6. Wilcoxon Ranks Test Result

\begin{tabular}{|ll|r|r|r|}
\hline & \multicolumn{1}{|c|}{$\mathrm{N}$} & \multicolumn{1}{c|}{$\begin{array}{c}\text { Mean } \\
\text { Rank }\end{array}$} & \multicolumn{1}{c|}{$\begin{array}{c}\text { Sum of } \\
\text { Ranks }\end{array}$} \\
\hline & $\begin{array}{l}\text { Negative } \\
\text { Ranks }\end{array}$ & $40^{\mathrm{a}}$ & 20.50 & 820.00 \\
Before- & $\begin{array}{l}\text { Positive } \\
\text { After }\end{array}$ & $0^{\mathrm{b}}$ & .00 & .00 \\
& $\begin{array}{l}\text { Ranks } \\
\text { Ties }\end{array}$ & $0^{\mathrm{c}}$ & & \\
& Total & 40 & & \\
\hline
\end{tabular}

Based on the data analysis, it can be concluded that the sequence activity model can improve children's motor skills $(\mathrm{P}<0.05)$.

\subsection{Discussion}

The serial-based physical education learning model in the form of a circuit has provided an opportunity for students to perform various muscle movements so that a fit condition is achieved. One of the objectives of learning physical education is to make physically fit. Movement of some muscles alone cannot have a comprehensive effect on the circulatory system or circulatory system, for this reason, a comprehensive range of motion, complex motion, involving many muscles and muscle coordination is required. Movement that is not sustainable has less impact on the body so that it is less helpful in achieving a fit condition. In order to achieve this balance, Circuit model-based physical learning is appropriate for preschool children because the sequential model studied contains many kinesthetic elements and the motion includes daily movements and being the mother of sports such as running, jumping, jumping, throwing, kicking, and twisting. By doing all the movements integrated in the circuit a fit condition is easier to achieve [13].

Physiological fitness is divided into two, namely fitness related to health and fitness related to performance or skills. Regarding health, the fitness of students has made their bodies more physically resilient to carry out activities both at school during class hours and outside the classroom when playing with their peers [14]. Children who are fit do not easily feel tired nor do they fall asleep easily. Associated with performance or skills, the physical fitness of children who perform various movements in the circuit can be seen from the child's ability to carry out daily movements [15]. Children can move faster, more agile, energetic and balanced.

The circuit model stimulates children's growth and development. When doing activities in station 1, children walk on the boardwalk, students train motor coordination so that body balance is achieved and does not fall off the board. Students combine the nervous system and movement in carrying out activities in harmony from several body parts. When children run or walk on the board, the child maintains balance by coordinating the movements of the hands and feet so as not to fall off the board. The child's ability to walk on the board trains dynamic balance, namely maintaining balance in moving conditions [16].

In station 2, when the child jumps over a number of hurdles, the child trains strength, speed while coordinating the legs, body and hands to maintain balance so that they are able to jump over the goal while running. The jumping movement also trains children's balance and power so they can jump without dropping the goal, children train their spatial development of when to jump and when not to jump [17].

In station 3 , the movement of running while rotating is indicated by the movement of the child moving the stick one by one by running forward and turning to train agility, to perform the movement of running while turning the direction requires high coordination [18]. Children who do running and twisting movements help strengthen the heart muscle, help improve blood circulation so that they can train their aerobic endurance. The circular motion to return to running forward trains flexibility besides having to remember the color of the stick that must be taken, this requires students to remember the sticks that must be taken next. 
In station 4, the movement of throwing a ball, children train coordination between eyes and hands. The throwing movement to aim at a target and the hope of hitting the target means training the feeling of motion how much force is needed to arrive and hit the target, and throwing towards the target means practicing accuracy, when making a movement to take the ball and return to the throwing position, then will train muscle flexibility. At the time of throwing students can practice counting how many balls are available, which hit the target when thrown and how many balls did not hit the target [19], [20].

In station 5, the movement of taking, putting and kicking the ball into the goal trains eye, hand and foot coordination. Coordination motion requires cooperation between the components of the body parts to carry out complete motion. In addition to training the coordination of kicking movements, they train muscle strength and leg muscle endurance. The movement of kicking as hard as possible and as quickly as possible has trained the power of students. When doing the movement of picking up the ball and returning to the kicking position, the child's muscle flexibility also develops [21]. The movement at station 5 can also be used to train the feeling of motion, counting the number of available balls, the number of balls that enter the goal and the number of balls that do not enter the target. In addition, children can also train to maintain balance to maintain body position while carrying out kicking tasks .

Serial-based physical learning in the form of circuits helps to improve physical fitness related to health fitness, although in fact there are many factors that can affect fitness achievement, both: exercise intensity, exercise frequency, specificity, condition of students, and motivation to practice.

Intensity is a workload that can be carried out by students to carry out the entire series of movements in the learning circuit. In this study the intensity was not measured, however, saw physiological signs that students were still able to do the next activity and were happy to try the next category with moderate intensity. The number of repetitions of the movement in the circuit determines the intensity, students who perform movements repeatedly show high intensity of exercise and are expected to produce better fitness than students who only do one movement [22].

The frequency of practice is the number of exercises carried out each week by students. If the circuit model learning is only run once, the intended fitness will not be achieved. Regular and measured exercise with sufficient frequency can make the muscles of the body become trained and make them fit [23], [24].

The specificity in question is every movement in each station in training certain types of movements aimed at training more specific elements of fitness. For example, jumping movements at station 2, throwing movements at station 4, kicking movements at station 5 train special muscles. If you only perform movements at certain stations, then the achievement of body fitness is not as good as if you do all the movements in the circuit. This means that the learning model in the form of a series guarantees the achievement of student fitness.

The biological or physical conditions of each student are certainly not the same. Body weight, height, body shape, health status, nutritional intake and strong or weak motivation also influence whether or not the objectives of the circuit-shaped physical learning model are achieved. Related to the motivation of each student, the circuit model successfully presents interesting and varied games. Movements in the circuit which include walking, running, jumping, throwing, kicking, crawling, crawling and climbing make physical learning in Kindergarten an interesting and fun game so that students are willing to do all the movements in the circuit repeatedly.

Physical learning based on a series of circuit models has succeeded in becoming a means for students to train all their muscles by performing a series of regular, measurable and continuous movements. Repeated learning will result in physiological adaptation to the given load so as to produce fitness related to health and movement skills in activities of daily life.

Physical learning of the circuit model is ideally carried out with careful preparation, that is, it is preceded by a warm-up. Heating that is carried out properly is physiologically very beneficial because by warming up it will cause changes in physiological functions in terms of: (a) Joint connective tissue will stretch so that the flexibility of joint motion will increase so that it can reduce the occurrence of muscle injury. (b) Blood circulation becomes smooth as a result of an increase in muscle temperature, so that the supply of oxygen and supply of energy in the tissues can be fulfilled. (c) Decreased vascular resistance and easier release of oxygen by hemoglobin as a result of dilation of blood vessels. (d) Muscle contraction will be more efficient due to lower viscosity [25], [26]. 
The various movements in the circuit, namely walking, running, jumping, twisting, throwing, kicking, crawling, creeping and climbing provide stimulation to students to make movements so that they can increase the sensitivity and maturity of the nervous system in determining the right reaction to these stimuli. Movement is a form of muscle response (neuromuscular) and is expressed in body exercise. Body movements can be classified into: reflex movements, reaction movements, fundamental movements, perceptual movements, bodily movements, skilled movements and non-discursive movements.

Movements in the circuit model when played together by two children will produce reflex and reaction movements. Reflex movements occur when walking on the board, crawling and climbing. When walking on the board, the child makes a reflex movement when he is about to fall. The child performs reflex movements when crawling touches the net above and the child performs a reflex when he is about to fall when climbing the net.

Motion reactions appear more when the circuit model is contested. Children will try to move faster than other participants so that the movements of other participants will always encourage children to give positive reactions, namely improving the quality of their movements, both running faster, throwing the ball on target, kicking the ball into the goal, arranging blocks faster and so on.

Various motions in the circuit contain elements of fundamental basic movements, namely basic movements that develop as a result of increasing age. Fundamental basic movements include: (a) locomotor movements, namely movements carried out by moving from one place to another such as walking on a board, jumping over poles, picking up sticks, crawling, creeping and climbing; (b) non-locomotor, namely movements that are carried out without having to move places such as throwing, kicking, and arranging blocks; (c) manipulative movements, namely by playing certain objects such as throwing, kicking, and arranging blocks [27], [28].

Perceptual movement is a movement that shows the ability to interpret the stimulus received by the five senses, the stimulus can be in the form of light, sound or touch. In circuit model physical learning, the stimulus comes from the accompaniment of music, the movement of other participants when being contested and the movement when determining the direction of throwing the ball. Movement of the body's ability that is processed in the circuit is the ability to function the body's organs in carrying out activities to process endurance, strength, flexibility, speed and agility .

When viewed from each movement in each station, not every movement can train students' motor development because the movements in each station are very limited or specific so that if the movements are carried out separately or individually, there is a tendency to easily cause boredom. the students. However, when the forms of games in physical learning are packaged in circuit models, they will be able to hone the body's kinesthetic abilities in various forms of movement as in the discussion above. Physical learning of this circuit model can be used to achieve fitness related to health or fitness related to performance or movement skills.

Serial-based physical education in this study is in accordance with the development of students so that students feel challenged to do it, but it is not difficult for students to do it. Movements that are too easy for students do not feel challenged to carry out activities, and do not feel as a success when they have subdued them, on the other hand, if the series of activities are too difficult, it becomes frustrating and unattractive.

Activities in serial-based physical learning with circuit models include challenging movements for students. Movements in the form of walking on the board, jumping over a number of small goals, throwing the ball on target, kicking the ball into the goal, crawling and climbing nets are challenging movements. It is said to be challenging because many students are interested in trying repeatedly before finally succeeding. This is in line with one of the principles of physical education, namely prioritizing successful experience.

Experience of success will not be fulfilled when the movement is too easy to do or too difficult to do. Movements that are too easy to do in the circuit model, namely the movement of moving sticks and arranging blocks are proven by the children's not being interested in trying these two movements. However, when assembled in a circuit, movements that are too easy become interesting and challenging movements because the movements that are seen as easy are part or conditions for carrying out movements at the next stage. When the circuit model is contested so that a competitive atmosphere emerges, all movements in the circuit are more interesting and create excitement for students to be actively involved in all physical education learning activities.

The ease of doing movements in the circuit is influenced by several factors, namely the teacher as a 
mentor and individual conditioning of each student, therefore, the teacher is required to provide examples of how to move across all the stations in the circuit. The example from the teacher not only shows the level of ease and difficulty of the game, but more importantly it provides an overview of the rules of the game from station 1 to the last station.

\section{CONCLUSION}

Physical Education Learning Based on a series consisting of 5 posts. Each post has a pressure point in providing stimulation of motor skills. The motor skills of preschool children can improve children's motor skills, it is proven that in the statistical test $\mathrm{P}>$ 0.05 .

\section{REFERENCES}

[1] B. Suhartini, "DETEKSI DINI KETERLAMBATAN PERKEMBANGAN MOTORIK KASAR PADA ANAK," MEDIKORA, vol. 1, no. 2, 2015, doi: 10.21831/medikora.v1i2.4770.

[2] C. Lightfoot, M. Cole, and S. R. Cole, "Physical and Cognitive Development in Early Childhood," Dev. Child., 2013.

[3] F. Valentina, E. Wulandari, and L. Nuraeni, "UPAYA UNTUK MENGEMBANGKAN KETERAMPILAN MOTORIK HALUS MELALUI AKTIVITAS ORIGAMI DENGAN METODE DEMONSTRASI PADA ANAK-ANAK KELOMPOK B DI TK BINA NUSANTARA," CERIA (Cerdas Energik Responsif Inov. Adapt., vol. 1, no. 4, 2019, doi: 10.22460/ceria.v1i4.p1-6.

[4] W. S. Suherman, Dapan, Guntur, and N. R. Muktiani, "Development of traditional children play based instructional model to optimize development of kindergarteners' fundamental motor skill," Cakrawala Pendidik., vol. 38, no. 2, 2019, doi: 10.21831/cp.v38i2.25289.

[5] K. O. Kippe and P. A. Lagestad, "Kindergarten: Producer or reducer of inequality regarding physical activity levels of preschool children," Front. Public Heal., vol. 6, no. DEC, 2018, doi: 10.3389/fpubh.2018.00361.

[6] M. V. Arie Paramitha and P. Sutapa, "Pengembangan Model Pembelajaran Berbasis Permainan Sirkuit Untuk Meningkatkan Motorik Halus Anak Usia 4-5 Tahun," J. Golden Age, vol. 3, no. 01, p. 1,
Jun. 2019, doi: 10.29408/goldenage.v3i01.1336.

[7] T. Wiestler and J. Diedrichsen, "Skill learning strengthens cortical representations of motor sequences," Elife, vol. 2013, no. 2, 2013, doi: 10.7554/eLife.00801.

[8] A. G. Lemos, E. L. Avigo, and J. A. Barela, "Physical Education in Kindergarten Promotes Fundamental Motor Skill Development," Adv. Phys. Educ., vol. 02, no. 01, 2012, doi: 10.4236/ape.2012.21003.

[9] T. H. Skarstein and I. B. Ugelstad, "Outdoors as an arena for science learning and physical education in kindergarten," Eur. Early Child. Educ. Res. J., vol. 28, no. 6, 2020, doi: 10.1080/1350293X.2020.1836590.

[10] T. K. Yeniningsih et al., "Motoric Development of Children Through a Variety of Greetings," J. SERAMBI ILMU, vol. 22, no. 1, 2021, doi: 10.32672/si.v22i1.2672.

[11] P. Sutapa, Y. Prasetyo, F. Arjuna, and H. Prihatanta, "Differences of Influence of Playing Playdough and Puzzles on Fine Motor Skills and Logical-Mathematical Intelligence in Early Childhood," 2019, doi: 10.2991/yishpess-cois-18.2018.44.

[12] B. Adiguna and P. Sutapa, "Challenges Of Inquiry Based Learning In Physical And Health Education," 2019, doi: 10.4108/eai.20-8-2019.2288092.

[13] A. Mylsidayu, J. Tangkudung, S. Hanif, Bujang, and D. Abidin, "Children circuit model for kids physical activity based blended learning," Int. J. Eng. Adv. Technol., vol. 8, no. 5, 2019, doi: 10.35940/ijeat.E1217.0585C19.

[14] P. I. Sari, "Upaya Meningkatkan Kemampuan Motorik Kasar Melalui Lompat tali," J. Pendidik. Guru PAUD SI, vol. 10, no. $1,2015$.

[15] M. Liparoti and R. Minino, "Rhythm and movement in developmental age," J. Hum. Sport Exerc., vol. 16, no. Proc3, 2021, doi: 10.14198/jhse.2021.16.Proc3.10.

[16] M. Rasoulzadeh et al., "A comparative study of dynamic and static balance status in childern with specific learning diability and normal childern," Koomesh, vol. 20, no. 1, 2018.

[17] D. Chan-Viquez et al., "Development of vertical and forward jumping skills in 
typically developing children in the context of referent control of motor actions," Dev. Psychobiol., vol. 62, no. 6, 2020, doi: 10.1002/dev.21949.

[18] F. B. Ortega et al., "Physical fitness and shapes of subcortical brain structures in children,” Br. J. Nutr., vol. 122, no. s1, 2019, doi: $10.1017 / \mathrm{S} 0007114516001239$.

[19] D. F. A. A. Derikx and M. M. Schoemaker, "The nature of coordination and control problems in children with developmental coordination disorder during ball catching: A systematic review," Hum. Mov. Sci., vol. 74, 2020, doi: 10.1016/j.humov.2020.102688.

[20] M. A. Sánchez-Lastra, S. Varela, J. M. Cancela, and C. Ayán, "Improving children's coordination with proprioceptive training," Apunt. Educ. Fis. y Deport., no. 136, 2019, doi: 10.5672/APUNTS.20140983.ES.(2019/2).136.02.

[21] R. P. Bendriyanti and M. Haryono, "Improving Gross Motor Skill By Traditional Games at Paud Gemilang in Bengkulu," J. Educ. Technol., vol. 5, no. 2, 2021, doi: 10.23887/jet.v5i2.34449.

[22] A. R. Nugraha and K. N. Berawi, "Pengaruh High Intensity Interval Training (HIIT) terhadap Kebugaran Kardiorespirasi," $J$. Major., vol. 6, no. 1, 2017.

[23] F. Suharjana, "MEMBINA KEBUGARAN JASMANI ANAK DENGAN SENAM PEMBENTUKAN," MEDIKORA, no. 1, 2015, doi: 10.21831/medikora.v0i1.4662.

[24] S. Suharjana, "ANALISIS PROGRAM KEBUGARAN JASMANI PADA PUSATPUSAT KEBUGARAN JASMANI DI YOGYAKARTA," MEDIKORA, 2015, doi: 10.21831/medikora.v11i2.2813.

[25] A. J. Fradkin, T. R. Zazryn, and J. M. Smoliga, "Effects of warming-up on physical performance: A systematic review with metaanalysis," J. Strength Cond. Res., vol. 24, no. 1, 2010, doi: 10.1519/JSC.0b013e3181c643a0.

[26] A. J. Fradkin, B. J. Gabbe, and P. A. Cameron, "Does warming up prevent injury in sport?. The evidence from randomised controlled trials?," Journal of Science and Medicine in Sport, vol. 9, no. 3. 2006, doi: 10.1016/j.jsams.2006.03.026.

[27] F. Fahrudin, M. Asmawi, F. Dlis, and R. Gustiawati, "Development Fundamental
Movement Learning Model Based On Team Games Tournament (TGT) For Elementary School Children," Kinestetik J. Ilm. Pendidik. Jasm., vol. 4, no. 2, 2020, doi: 10.33369/jk.v4i2.12599.

[28] Y. Kiram, A. Komaini, and N. W. Pranoto, "Development of Fundamental Basic Movement Skill of Children," 2020, doi: 10.2991/assehr.k.200824.088. 